\title{
高分子物質の燃焼熱と酸菜指数について
}

\author{
(1975 年 1 月 13 日 受理)
}

\author{
大江 秀 雄・松 浦 貢一*
}

高分子物質，軽油の燃焼熱，酸蜏指数などの文献值を使用して下記の式が成立することを認めた。

1) $H_{\mathrm{cs}}\left(\mathrm{cal} / \mathrm{cm}^{3}\right)=1456+84220 L O\left(\mathrm{~mol} / \mathrm{cm}^{3}\right)$

$H_{\mathrm{o}}(\mathrm{cal} / \mathrm{g})=744+92605 \mathrm{LO}(\mathrm{mol} / \mathrm{g})$

$O I=0.0126 M H E F(\mathrm{kcal} / \mathrm{mol})-0.036$ （高分子試料 8 +軽油試料 10)

$O I=0.0129$ MHEF $(\mathrm{kcal} / \mathrm{mol})-0.044$ (高分子陚料 8)

ここに, $H_{\mathrm{cc}}, H_{0}$ はとれぞれ被燃焼体 $1 \mathrm{~cm}^{2}, 1 \mathrm{~g}$ あたりの $\mathrm{cal}$ 単位燃焼熱, LO は限界酸素量 $m_{\mathrm{o}} /$ $M V, M H E F$ は限界熱流束平均エネルギー, $O I$ は酸素指数を示す。

$M H E F=H_{\mathrm{co}} /\left[\left(m_{\mathrm{p}}+m_{\mathrm{n}}\right) / M V\right], M V$ は軽油のモル容積あるいは高分子単位鎖員分子の容積 $\left(\mathrm{cm}^{3}\right)$, $m_{\mathrm{o}}, m_{\mathrm{n}}, m_{\mathrm{p}}$ はそれぞれ軽油分子あるいは高分子単位鎖員分子 $1 \mathrm{~mol}$ が酸素指数組成の雲囲気で自己火 炎燃焼をつづける場合に参与する酸素，空素のモル数および生成ガスの総モル数を示す。

2）化学異性体を含めた諸種の単元重合体，エチレンー眽酸ビニルおよびエチレンープロピレン共重合 体などの然燒熱，酸素指数を実莭して上式からの推定值と比較し式の有用性を認めた。

3）酰酸ビニルーエチンン，エチレン共重合体の酸素指数は組成相加平均值より前者は高く，後者は 組成相加平均值を越光なかった。

\section{1 粕}

Fenimore $5^{1}$ )は，高分子物質の酸素指数（以下 $O I$ と略記す る）の測定法を開発し，そのOI 値を基準として高分子物質の燃 焼性の序列ずけが可能であることを示した。これよりさき，Wolfhard $5^{23}$ は，然料ガス，軽油ガスが化学量論的比率で酸化剂に 出会らと仮定して，OI 成分量に相応する空素量で薄められた酸 素量と $1 \mathrm{~mol}$ の然料との混合炎 (premixed flame) とOI 值を 示す雾囲気下の拡散炎との火炎温度が一致することを認めた。

たとえばエタンの化学量論的酸素, 窒素の混合焱は

$$
\mathrm{C}_{2} \mathrm{H}_{8}+3.5 \mathrm{O}_{2}+3.5((1-O I) / O I) \mathrm{N}_{2}
$$

の組成をつっ。

$1 \mathrm{~mol}$ の然料に対する酸素, 窒素のモル数をそれぞれ $m_{0}, m_{\mathrm{n}}$ で表わせば，OI は限界条件における外気の酸素容積濃度を示す。

$$
O I=m_{\mathrm{o}} /\left(m_{\mathrm{o}}+m_{\mathrm{n}}\right), m_{\mathrm{n}}=[(1-O I) / O I] m_{\mathrm{o}}
$$

と表示できる。また燃料 $1 \mathrm{~cm}^{8}$ あたりのモル数の比として表示 も可能である。

$$
\begin{aligned}
& O I=\left(m_{\mathrm{o}} / M V\right) /\left[\left(m_{\mathrm{o}}+m_{\mathrm{n}}\right) / M V\right] \\
& M V: \text { 燃料 } 1 \mathrm{~mol} \text { の体積. }
\end{aligned}
$$

従来，高分子物質の燃焼熱と燃燒現象との間になにか関係があ

* 福井大学工学部織䊒染料学科, 910 福井市文京

1) C.P. Fenimore, F.J. Martin, Modern Plastics, Nov., $141(1966)$.

2) R. F. Simmons, H. G. Wolfhard, Combustion and Flame, 1, 155 (1957).
るのではないかとしているいろの研究がなされた。

Krekeler らクは，焱莾性と然焼熱との間にはなんら直接関係は ないとしている。Chatainらかは，ポリ塩化ビニル系列で OI と然 焼熱 (cal/g) との間に反比例的関係が存在することを報告してい る。Martin') は， $n_{0 x} / n_{1}$ (限界酸素量と不活性ガス整との比) と 不活珄ガスの熱容量との間任直線関俰が成立することを器めた。

Johnson ${ }^{6)}$ は, $O I=1.9 /$ 比然焼熱 (cal/g) なる関係式が主とし て炭水化物系高分子物質について成立するとしたが，ポリフクリ ロニトリル,ポリビニルアルコール, ポリオキシメキレン, ポリエ チレンテレフタテートなど（以下それぞれ PAN, PVA，PMO， PET と略記する）は適用されない。またなんらかの形で（全炭

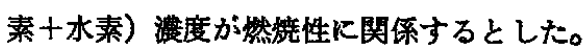

Nelson らりは，液体について $1 \mathrm{~cm}^{3}$ あたりの然燒熱が OI の 逆数とよりよい相関を示すとしている。

$O I$ 算定の因子である酸素量, 窒亲量が然焼とどんな関俰をる つかを知ることは $O I$ をよりよく理解する上に重要である。

$O I$ 之燃燒熱との間のなんらかの関係を求める場合下，空素の 役割りについては，消资効果のみを考えがちではあるが，然焼に より生成した燃焼熱を生成ガスととるにかけ合って未然新への 火炎层播、然焼サイクル持続の役目をする熱流束の主要成分とな

3) K. Krekeler, P. M. Klimke, Kunststoffe, 55, 155 (1953).

4) M. Chatain, L. Chesné, Revue Gén. Caoutchoucs et Plastiques, 50, 695(1973).

5) F. J. Martin, Combustion and Flame, 12, 125 (1968).

6) P. R. Johnson, J. Appl. Polym. Sci., 18, 491 (1974).

7) G. L. Nelson, J. L. Webb, J. Fire and Flammability, 4. 210 (1973). 
る事実を忘れてはならない。

$6.5 \times 3 \mathrm{~mm}$ の断面積をるった棒状高分子材料の上端に火源に より，ろらそく状の火炎を灯し，対流をとるなわない限界罢囲気 で上より下に向けて云播させた場合息の火炎の化学組成分析を低 密度ポリエチレンについて行なったのが Burge ら゚である。

溶融表面にきわめて近い上部ガス組成は，窒素70，一酸化炭素 5, 二酸化炭素 10 ，水蒸気 5, 小計 $90 \%$ であり，酸素<2\%を 除いた残部はエチレン分の濃い低分子量炭化水素であるとしてい る。この結果恃霝囲気の酸素は $O I$ 測定において少ない損失で然 莾にあずかっていること，および軽油の限界混合炎の組成が化学 量論的に $1 \mathrm{~mol}$ の軽油と酸素指数に対沁する空素で薄められた 酸素量とからなり立っているといら関係を高分子物質の $O I$ を梌 砷するのに拡張使用が可能であることを示す。祭囲気の酸素が損 失なく燃煍に参与するとし，燃焼熱と限界条件における酸素量と の関係式を求めるにつついて，限界条件における秷素量す損失な く生成ガスの保有する熱量を平均化するとして限界熱流東平均エ ネルギー（以下 $M H E F$ と略記する）なる量を設定して OI 倠と の関係を追跡することが考兄られる。

$$
M H E F=\frac{H_{\mathrm{oc}}}{\left(m_{\mathrm{p}}+m_{\mathrm{n}}\right) / M V}(\mathrm{cal} / \mathrm{mol})
$$

ここK, $H_{\mathrm{cc}}$ : 商分子物賀 $1 \mathrm{~cm}^{\mathrm{s}}$ あたりの然嫃熱 $\left(\mathrm{cal} / \mathrm{cm}^{\mathrm{s}}\right)$, $m_{\mathrm{p}}$ ：高分子鎮員分子単位（以下 $1 \mathrm{~mol}$ と略記する）を然焼す るとき生成するガスの総モル数， $M V$ ：高分子 $1 \mathrm{~mol}$ の体積 $\left(\mathrm{cm}^{3}\right)$ とする.

火炎伝播において単位容積の材料を取り囲む熱流束の量が大き

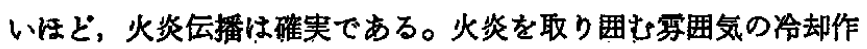
用から守ってくれる。また熱流束の限界に打ける平均熱量が小さ いほど，外気との温度差が小で火炎伝播に必要な熱量の維持が容 易となる ${ }^{10 \%}$ 。なお限界とは然焼票囲気の酸素, 窒菜量が $O I$ 値の 組成と同一の意である。

著者らはまず Krekeler ら》, Chatain ら少の求めた高分子材料

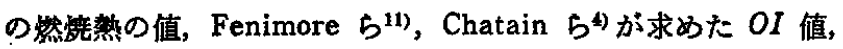
軽油については Wolfhard $5^{2)}$ が求めた $O I$ 值を利用して燃焼 熱 ( $\left.\mathrm{cal} / \mathrm{cm}^{3}, \mathrm{cal} / \mathrm{g}\right)$ と限界酸素量との関係式, OI 值と $M H E F$ 值との関係式を求めた。つぎにこれらの式に単元および共重合体 のOI 值を代入して然焼熱を推定, 二式からの推定檤の近似性を くらべた。最後に高分子物質の燃熱を実測し推定量との近似， 式の有効性を確かめ, かつ近似性の内容飞ついて検討した。

\section{2 計算の基礪}

2.1 燃焼熱 $\boldsymbol{H}_{\mathrm{o}}(\mathrm{cal} / \mathrm{g}), \boldsymbol{H}_{\mathrm{cc}}\left(\mathrm{cal} / \mathrm{cm}^{3}\right)$

前者は Krekeler ${ }^{3)}$, Chatain 54)の文献値, 後者は密度を用い 一算出 ${ }^{12)}$, 軽油江便筧檤 ${ }^{13)}$ 。

8） ASTM, D 2863-70；須賀 蒢，ブラスチック，21，7 (1971).

9) S. J. Burge, C.F.H. Tipper, J. Combustion and Flame $13,495(1969)$.

10）秋田一雄，高分子，22，184(1973）；I. Skeist, "Reviews in Polymer Technology", Vol.1, Marcel Decker, Inc, New York (1972) p. 113.

11) C. P. Fenimore, F. J. Martin, Combustion and Flame, 10, 135(1966).

12) P. M. Klimke, 私信, Nov. 21(1973); M. Chatain, 私信, Jan. 10(1974).

13）“然料便覽”。丸善(1953) p. 45.

\section{$2.2 O I$}

Fenimore $^{11)}$, Chatain ${ }^{4)}$, Wolfhard ${ }^{2)}$ らの文献値。

2.3 限界酸量(以下 $L O$ と略記する, $\mathrm{mol} / \mathrm{cm}^{3}$ または $\mathrm{mol} /$ g)，限界窒素贵（以下 $L N$ と略記する， $\mathrm{mol} / \mathrm{cm}^{8}$ または $\mathrm{mol} / \mathrm{g}$ )

$$
L O=m_{\mathrm{o}} / M V, L N=m_{\mathrm{n}} / M V
$$

以下ナイロンー6を例として説明する。

$1 \mathrm{~mol} 113 \mathrm{~g}$, 密度 $1.10 \mathrm{~g} / \mathrm{cm}^{3}$, モル容稓 $(M V) 102.72 \mathrm{~cm}^{3}$, OI $0.26, H_{\text {cc }} 8108 \mathrm{cal} / \mathrm{cm}^{9}$

然㜔式を示すと。

$$
\begin{aligned}
& -\mathrm{NH}\left(\mathrm{CH}_{2}\right)_{8} \mathrm{CO}+8.25 \mathrm{O}_{2} \rightarrow 6 \mathrm{CO}_{2}+5.5 \mathrm{H}_{2} \mathrm{O}+0.5 \mathrm{~N}_{2} \\
& m_{\mathrm{o}}=8.25, m_{\mathrm{n}}=23.31, m_{\mathrm{p}}=12.0 \\
& L O=8.25 / 102.72=0.08, L N=23.31 / 102.72=0.23
\end{aligned}
$$

\section{4 限界熱流束 $\left(\mathrm{mol} / \mathrm{cm}^{3}\right)$ (以下 $\boldsymbol{L H F}$ と略記する)}

$L H F=\left(m_{\mathrm{p}}+m_{\mathrm{n}}\right) / M V=(12+23.31) / 102.72=0.35$

\section{5 限界熱流束平均エネルギー $(M H E F)(\mathrm{kcal} / \mathrm{mol})$}

$$
M H E F=8110 / 0.35=23.46
$$

\section{6 共重合体の取り扱い}

エチレンー酶酸ビニル共重合体, Evaflex-40, $-150,-460,-550$ は それぞれ䣫酸ビニル，40，33，20，14\%を含有する。1 mol を次 式で示すと,

\section{$-\left(\mathrm{CH}_{2} \mathrm{CH}_{2}\right)_{1}\left(\mathrm{CH}_{2} \mathrm{CHOCOCH}\right)_{x^{-}}$}

$x$ の値はそれぞれ $0.22 ， 0.16 ， 0.08 ， 0.05$ となる。限界にお けるポリエチレン, ポリ酭酸ビニルの然焼は次式で示される。

$$
\begin{aligned}
& -\mathrm{CH}_{2} \mathrm{CH}_{2}-3 \mathrm{O}_{2}+3[(1-0.173) / 0.173] \mathrm{N}_{2} \\
& \longrightarrow 2 \mathrm{CO}_{2}+2 \mathrm{H}_{2} \mathrm{O}+14.34 \mathrm{~N}_{2} \\
& -\mathrm{CH}_{2} \mathrm{CHOCOCH}_{3}+4.50_{2}+4.5[(1-0.202) / 0.202] \mathrm{N}_{2} \\
& \quad \longrightarrow 4 \mathrm{CO}_{2}+3 \mathrm{H}_{2} \mathrm{O}+17.65 \mathrm{~N}_{2}
\end{aligned}
$$

したがってたとえば Evaflex-40 の然焼式は，

$$
\begin{gathered}
-\left(\mathrm{CH}_{2} \mathrm{CH}_{2}\right)_{1}\left(\mathrm{CH}_{2} \mathrm{CHOCOCH}_{3}\right)_{0.22-}+3.98 \mathrm{O}_{2}+14.19 \mathrm{~N}_{2} \\
\longrightarrow 2.87 \mathrm{CO}_{2}+2.65 \mathrm{H}_{2} \mathrm{O}+14.19 \mathrm{~N}_{2}
\end{gathered}
$$

となる。

ここК, $1 \mathrm{~mol} 28+0.22 \times 86=46.66, \quad O I=0.219, \quad m_{0}=3+$ $4.5 \times 0.22 ; m_{\mathrm{n}}=3.98[(1-0.219) / 0.219] ; m_{\mathrm{p}}=4+7 \times 0.22 ;$; 密 度 $0.97, M V=48.11 \mathrm{~cm}^{3}$

エチレンープロピレン共重合体 (Et-PP)-A，-B，-C はそれぞれ プロピレン $30,40,50 \%$ を含有する。 $1 \mathrm{~mol}$ を $-\left(\mathrm{CH}_{2} \mathrm{CH}_{2}\right)_{1}$. $\left(\mathrm{CH}_{2} \mathrm{CHCH}_{9}\right)_{x}$ - で示すと，xはそれぞれ $0.29 ， 0.44 ， 0.67$ とな る。以下 Evaflex 飞淮じて取り扱ら。

\section{3 実験}

\section{1 試 料}

ポリエチレン (PE，三井石油化学)，ポリブロビレン (PP, 住 友化学), ポリスチレン (PS, 三菱モンサント化成), ポリアミド (Ny-6, 東洋紡繈), PVA (クラレ), ポり酸酸ビニル (PVAc, ク

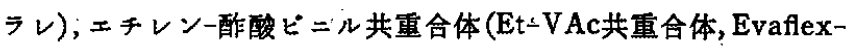
$40,-150,-460,500$, 三井ポリケミカル)，エチレンープロピレン共 重合体(Et-PP 共重合体- $\mathrm{A},-\mathrm{B},-\mathrm{C}$, 住友化学), ポリ(メタクリ 
Table 1 Oxygen index, heat of combustion, density, molar volume, limiting amounts of oxygen, nitrogen and heat flux, and mean heat energy of limiting heat flux of high polymers

\begin{tabular}{|c|c|c|c|c|c|c|c|c|c|}
\hline No. & Material & $O I$ & $\begin{array}{l}H_{\mathrm{o}}(\mathrm{K}) \\
(\mathrm{cal} / \mathrm{g})\end{array}$ & $\begin{array}{c}\text { Density }(k) \\
\left(\mathrm{g} / \mathrm{cm}^{8}\right)\end{array}$ & $\begin{array}{c}M V \\
\left(\mathrm{~cm}^{\mathrm{s}}\right)\end{array}$ & $\underset{\left(\mathrm{mol} / \mathrm{cm}^{\mathrm{s}}\right)}{L O}$ & $\underset{\left(\mathrm{mol} / \mathrm{cm}^{\mathrm{g}}\right)}{L N}$ & $\begin{array}{c}L H F \\
\left(\mathrm{~mol} / \mathrm{cm}^{3}\right)\end{array}$ & $\begin{array}{c}M H E F \\
(\mathrm{kcal} / \mathrm{mol})\end{array}$ \\
\hline 2 & PE & $0.173(\mathrm{C})$ & 10965 & 0.92 & 30.43 & 0.10 & 0.47 & 0.60 & 16.74 \\
\hline 3 & PP & $0.174(C)$ & 10506 & 0.91 & 46.15 & 0.10 & 0.46 & 0.59 & 16.12 \\
\hline 5 & PS & $0.181(\mathrm{C})$ & 9604 & 1.05 & 99.05 & 0.10 & 0.46 & 0.58 & 17,43 \\
\hline 8 & $\mathrm{Ny}-6$ & $0.26(\mathrm{C})$ & 7371 & 1. 10 & 102.73 & 0.09 & 0.23 & 0.35 & 23. 29 \\
\hline 9 & Polycarbonate & 0.26 (F) & 7294 & 1.20 & 211.70 & 0.09 & 0.24 & 0.36 & 24.60 \\
\hline 10 & PMMA & $0.182(\mathrm{C})$ & 6265 & 1.18 & 84.74 & 0.07 & 0.32 & 0.42 & 17.43 \\
\hline 18 & $\mathrm{PVCl}$ & $0.45(\mathrm{~F})$ & 4315 & 1.38 & 45.29 & 0.05 & 0.07 & 0.16 & 38.20 \\
\hline 21 & PMO & 0.148 (F) & 4043 & 1.40 & 21.43 & 0.05 & 0.27 & 0.36 & 15.83 \\
\hline
\end{tabular}

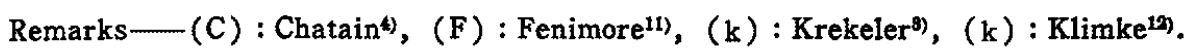

Table 2 Oxygen index, heat of combustion, density, molar volume, limiting amounts of oxygen, nitrogen and heat flux, and heat energy of limiting heat flux of light fuels

\begin{tabular}{|c|c|c|c|c|c|c|c|c|c|}
\hline No. & Materials & $O I(W)^{2)}$ & $\begin{array}{c}H_{\mathrm{o}}{ }^{18)} \\
(\mathrm{cal} / \mathrm{g})\end{array}$ & $\begin{array}{l}\text { Density } \\
\left(\mathrm{g} / \mathrm{cm}^{3}\right)\end{array}$ & $\underset{\left(\mathrm{cm}^{3}\right)}{M V}$ & $\begin{array}{c}L O \\
\left(\mathrm{~mol} / \mathrm{cm}^{2}\right)\end{array}$ & $\begin{array}{c}L N \\
\left(\mathrm{~mol} / \mathrm{cm}^{2}\right)\end{array}$ & $\underset{\left(\mathrm{mol} / \mathrm{cm}^{3}\right)}{L H F}$ & $\begin{array}{c}M H E F \\
(\mathrm{kcal} / \mathrm{mol})\end{array}$ \\
\hline $4^{\prime}$ & Pentane & 0.1325 & 11809 & 0.63 & 115.38 & 0.07 & 0.46 & 0.55 & 13.42 \\
\hline $5^{\prime}$ & Hexane & 0.1335 & 11547 & 0.66 & 130.90 & 0.07 & 0.47 & 0.57 & 13. 30 \\
\hline $6^{\prime}$ & Octane & 0.134 & 11447 & 0.70 & 162.62 & 0.08 & 0.50 & 0.75 & 13. 35 \\
\hline $7^{\prime}$ & Decane & 0.1345 & 11386 & 0.73 & 175.05 & 0.08 & 0.52 & 0.63 & 13. 21 \\
\hline $8^{\prime}$ & Methanol & 0.111 & 5330 & 0.79 & 40.35 & 0.04 & 0.29 & 0.37 & 11.37 \\
\hline $9^{\prime}$ & Ethanol & 0.126 & 7090 & 0.79 & 59.66 & 0.05 & 0.34 & 0.42 & 13.00 \\
\hline $10^{\prime}$ & Propanol & 0.128 & 8020 & 0.80 & 62.19 & 0.07 & 0.49 & 0.61 & 14.22 \\
\hline $22^{\prime}$ & Cyclohexane & 0.134 & 11133 & 0.78 & 102.56 & 0.09 & 0.57 & 0.68 & 13. 33 \\
\hline $23^{\prime}$ & Benzene & 0.133 & 9999 & 0.88 & 88.64 & 0.09 & 0.56 & 0.66 & 13. 39 \\
\hline $24^{\prime}$ & Acetone & 0.1285 & 7400 & 0.79 & 73. 32 & 0.06 & 0.37 & 0.45 & 12.96 \\
\hline
\end{tabular}

Remark-(W) : Simmons and Wolfhard2).

ル酸メチル) (PMMA, 市肘品), ボリ塩化ビ二ル（PVCl, 日本 ぜン)、ボリェチレンオキシド (PEO, 三洋化成)

\section{2 測定項目}

a ) 燃焼熱 (cal/g) : YM 改良 B 型燃研式断熱熱量計（吉田製 作所）と租み合わせて熱量測定を自動化したサーミスタカロリー メーターY-0100 (宝工業)。試料は $O I$ 测定用に成型した一部 分。測定回数約 10 回の平均値，母数推定標準偏差，\%表示变動 䋆数。

b) $O I:$ Oxygen-Indexer (東洋精機)。試料 : ペレットを6.5 $\times 3 \times 150 \mathrm{~mm}$ に成型。

c）密度：密度勾配管または浮沈法，製造者の値と一致。

\section{4 計算結果と注黔}

㖕算に使用した高分子物質の $O I, H_{0}$ ，密度， $M V, L O, L N$ ， $L H F, M H E F$ を表 1 に，軖油のそれを表 2 に示す。

\section{1 高分子物質の撚焼熱と限界酸素量との関保}

$L O(\mathrm{~mol} / \mathrm{g}) を x$ 軸飞 $H_{\mathrm{o}}(\mathrm{cal} / \mathrm{g})$ を $y$ 軸に，あるいは $L O(\mathrm{~mol} /$ $\left.\mathrm{cm}^{3}\right)$ を $x$ 軸に $H_{\mathrm{cc}}\left(\mathrm{cal} / \mathrm{cm}^{3}\right)$ を $y$ 軸にとると直線関係が見られ る。最小二乗法で直線式を表わせば

$$
\begin{aligned}
& H_{\mathrm{cc}}\left(\mathrm{cal} / \mathrm{cm}^{9}\right)=1456+84220 L O\left(\mathrm{~mol} / \mathrm{cm}^{3}\right) \\
& H_{0}(\mathrm{cal} / \mathrm{g})=744+92605 L O(\mathrm{~mol} / \mathrm{g})
\end{aligned}
$$

となる。試料数 $n=8$ 。図 1 に上に述べた模様を示す。

\section{2 酸素指数と限界熱流束平均エネルギ一との関保}

$O I$ を $y$ 軸に, MHEF を 軸にとると直線関係が見いだされ

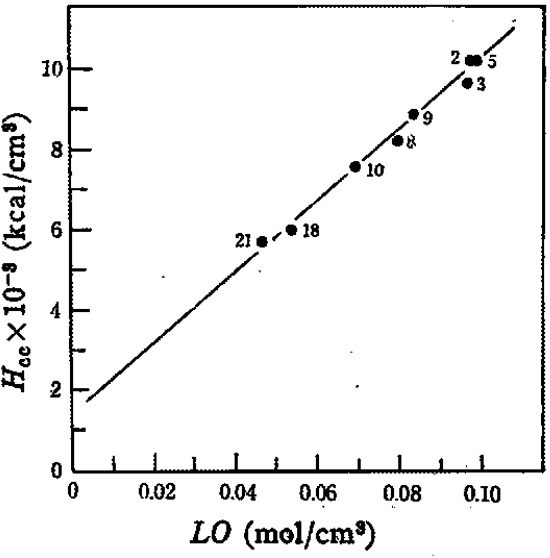

Fig. 1 Heat of combustion ( $H_{\mathrm{cc}}$ ) vs. limiting oxygen amount $(L O)$

る。高分子物質 8 試料と軽油 10 試料計 18 試料について最小二 乗法でその直線を求めると

$$
O I=0.0126 M H E F-0.036
$$

高分子物質 8 陚料のみについては

$$
O I=0.0129 M H E F-0.044
$$

图 2 に式(15)の模様を示す。

\section{3 注 粎}

燃燒熱之限界酸素量との関係において，然焼する材料 $1 \mathrm{~cm}^{\mathbf{3}}$ あ たり，1g あたり，1 mol あたりとするかで対応する然焼熱る 


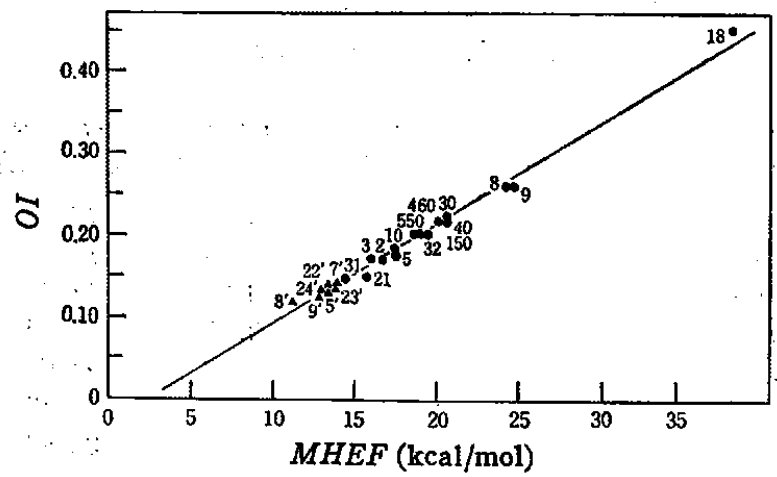

Fig. 2 Oxygen index vs. mean heat energy of limiting heat flux $(M H E F)$

$\mathrm{cal} / \mathrm{cm}^{\mathrm{s}}, \mathrm{cal} / \mathrm{g}, \mathrm{kcal} / \mathrm{mol}$ と単位が变わる。限界酸素量 $(\mathrm{mol} /$ $\left.\mathrm{cm}^{9}\right)$ と $H_{\mathrm{ce}}$ との比を示す式は,

$H_{\mathrm{ce}} /\left(m_{\mathrm{o}} / M V\right)=\left(H_{\mathrm{o}} \cdot d\right) /\left[m_{\mathrm{o}} /(M W / d)\right]=\left(H_{0} \cdot M W\right) / m_{\mathrm{o}}$

となる。ここに， $d$ は密度， $M W$ は分子量 $(\mathrm{g})$ 。

式（16）の意味は高分子 $1 \mathrm{~mol}$ を燃烧するに外部から与える必 要のある酸素 1 mol とつき発生しらる然焼熱量である。これに対 して OI-MHEF 式の関係は

$$
\begin{gathered}
\left.M H E F=H_{\mathrm{cc}} /\left(m_{\mathrm{p}}+m_{\mathrm{n}}\right) / M V\right]=\left(O I \cdot H_{\mathrm{o}} \cdot M W\right) / \\
{\left[O I\left(m_{\mathrm{p}}-m_{\mathrm{o}}\right)+m_{\mathrm{o}}\right]} \\
M H E F / O I=\left(\dot{H}_{\mathrm{o}} \cdot M W\right) /\left[O I\left(m_{\mathrm{p}}-m_{\mathrm{o}}\right)+m_{\mathrm{o}}\right]
\end{gathered}
$$

と整理される。式(16)では燃等熱を $m_{0}$ のみと関係ずけているに

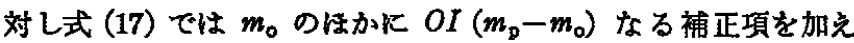
ることにより，材料分子内部に存在する空素，酸素，塩素などの 寄与を認め，かつその大きさはOI $\left(m_{\mathrm{p}}-m_{\mathrm{o}}\right)$ であると規定してい ることになる。事実後で述べように MHEF-OI 式を用いて OI 実剆値から矮焼熱を算出した值は実測值に近い。然焼に必要な外

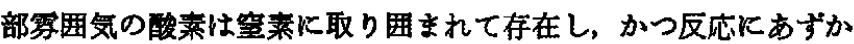
るのであるから生成ガスにとるなわれて生成する然焼熱を外界の 空素 $m_{\mathrm{n}}$ が生成ガス $m_{\mathrm{p}}$ とかから合い平均化して熱流東を形成寸 る。
この平均化された熱流束の熱量が流束量とともに火炎伝播に寄 与するという仮定には生成ガス，空素の熱层導保数，熱容量など は同一との仮定も含まれている。

$O I$ そ $M H E F$ との関係は軽油す含んで成立しているが，ここ ではふれない。

\section{5 実測值との比較}

PVA とPEO とは化学異性体である。OI値はそれぞれ 0.224, 0.150 と異なっているが然焼式は同一式で示される。

$$
\begin{aligned}
& -\left(\mathrm{CH}_{2} \mathrm{CH}_{2} \mathrm{O}\right)-\text { or }-\left(\mathrm{CH}_{2} \mathrm{CHOH}\right)-+2.5 \mathrm{O}_{2} \longrightarrow \\
& \quad 2 \mathrm{CO}_{2}+2 \mathrm{H}_{2} \mathrm{O}
\end{aligned}
$$

実測然燒熱も後で述べるように両者で粠なっているが，然焼熱 と重量またはモル単位で表示した限界酸素量との関係からは然焼 熱の差悦見いだしがたい。

一方，Tesoro らによると PET と綿との混紡品の OI は二成 分単独のときの $O I$ 值の組成相加平均值より下まわる傾向比あ $\eta^{1 k)}$, Nomex (環状ナイロン) とVerel (淮アクリル瀻維)の混 赤品の $O I$ 値は単独成分のときの相加平均値より上まわる傾向に ある16。

共重合体の OI 值とそれぞれの成分の $O I$ 值との関係はどう 加。

PVA，PE0，PVAc， 4 種類の眽酸ビニル含有量を巽にする Evaflex の実測 $O I$ 值，算出 $M H E F, H_{\mathrm{cc}}$ 值などを表 3 亿示す。 （12）式からの推定値はカッコあり，(15）式からの計算値はカッ コなしで示す。

最後飞 PE, PP, PS, Ny-6, PMMA, Et-PP 共重合体およ゙表 3の試料の燃焼熱，OI 值を測定し，式 (12)，(15）からの計算然 焼熱值との比褺をしたるのが表 4 の結果である。

表中の記号 s.d. は皮数推定標準偏差, nは測定回数, c.v. は \%表示変動係数である。単元重合体の実測と推定燃焼熱の值の差

\begin{tabular}{|c|c|c|c|c|c|c|c|c|c|}
\hline No. & Materials & $O r$ & $\underset{\left(\mathrm{mol} / \mathrm{cm}^{3}\right)}{L O}$ & $\stackrel{L N}{\left(\mathrm{~mol} / \mathrm{cm}^{8}\right)}$ & $\begin{array}{c}L H F \\
\left(\mathrm{~mol} / \mathrm{cm}^{3}\right)\end{array}$ & $\begin{array}{l}\text { Density } \\
\left(\mathrm{g} / \mathrm{cm}^{3}\right)\end{array}$ & $\begin{array}{c}M V \\
\left(\mathrm{~cm}^{3}\right)\end{array}$ & $\begin{array}{c}M H E F \\
(\mathrm{kcal} / \mathrm{mol})\end{array}$ & $\begin{array}{c}H_{\mathrm{cc}} \\
\left(\mathrm{cal} / \mathrm{cm}^{a}\right)\end{array}$ \\
\hline 30 & PVA & 0.225 (F) & 0.07 & 0.25 & 0.37 & 1.29 & 34.11 & $\begin{array}{c}20.92 \\
(20.66)\end{array}$ & $\begin{array}{c}7690 \\
(7600)\end{array}$ \\
\hline 31 & PEO & $0.150(F)$ & 0.07 & 0.39 & 0.50 & 1. 22 & 36.21 & $\begin{array}{c}15.09 \\
(14.48)\end{array}$ & $\begin{array}{c}7580 \\
(7270)\end{array}$ \\
\hline 32 & PVAC & 0.202 & 0.06 & 0.24 & 0.34 & 1.18 & 72.88 & $\begin{array}{c}19.13 \\
(19.57)\end{array}$ & $\begin{array}{c}6500 \\
(6650)\end{array}$ \\
\hline 40 & $\begin{array}{l}\text { Evaflex } \\
40 \% \text {-VAc }\end{array}$ & 0.219 & 0.08 & 0.30 & 0.41 & 0.97 & 48. 11 & $\begin{array}{c}20.45 \\
(20.56)\end{array}$ & $\begin{array}{c}8370 \\
(8421)\end{array}$ \\
\hline 150 & $33 \%$-VAc & 0.219 & 0.09 & 0.30 & 0.41 & 0.96 & 44. 44 & $\begin{array}{c}20.45 \\
(20.50)\end{array}$ & $\begin{array}{c}8570 \\
(8600)\end{array}$ \\
\hline 460 & $20 \%$-VAc & .0 .202 & 0.09 & 0.37 & 0.49 & 0.94 & 36.87 & $\begin{array}{c}19.13 \\
(18.41)\end{array}$ & $\begin{array}{c}9460 \\
(9100)\end{array}$ \\
\hline 550 & $14 \%$ "VAc & 0.202 & 0.09 & 0.37 & 0.49 & 0.93 & 35.01 & $\begin{array}{c}19.13 \\
(18.85)\end{array}$ & $\begin{array}{c}9380 \\
(9250)\end{array}$ \\
\hline
\end{tabular}
を平均値で比較すると，OI-MHEF 式 $86 \mathrm{cal} / \mathrm{g}, H_{\mathrm{cc}}-L O$ 式 228 $\mathrm{cal} / \mathrm{g}$ で前者がよりよい近似を示す。PVA, PEO 化学翼性体化つ いても実測値に近接する。

Table $3 M H E F$ and $H_{\mathrm{cc}}$ calculated from the equations of $H_{\mathrm{cc}}-L O$ (12) and $O I-M H E F$ (15)

Remark $M H E F$ and $H_{\mathrm{ce}}$ : With and without parenthesis represent the values calculated from the equations (12) and (15) respectively. (F) : Fenimore ${ }^{(1)}$.

14) G. C. Tesoro, C. H. Meiser, Text. Res. J., 40, 430(1970).

15) G. C. Tesoro, J. Rivin, J. Amer. Assoc. Textile Corosist, 3, 156(1971). 
Table 4 Heats of combustion and oxygen indices observed, and heats of combustion calculated

\begin{tabular}{|c|c|c|c|c|c|c|c|c|c|c|c|}
\hline \multirow{2}{*}{ No. } & \multirow{2}{*}{ Material } & \multirow[t]{2}{*}{$n$} & \multirow{2}{*}{$H_{\mathrm{o}}\left(\begin{array}{c}\text { (observed) } \\
(\mathrm{cal} / \mathrm{g})\end{array}\right.$} & \multirow{2}{*}{ s. d. } & \multirow{2}{*}{$\begin{array}{l}\text { c. v. } \\
(\%) .\end{array}$} & \multirow{2}{*}{$O I$} & \multirow{2}{*}{$\begin{array}{l}\text { Density } \\
\left(\mathrm{g} / \mathrm{cm}^{2}\right)\end{array}$} & \multicolumn{2}{|c|}{ 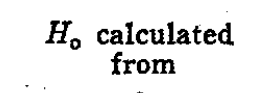 } & \multicolumn{2}{|c|}{$\begin{array}{l}\text { Difference of } H_{\circ} \text { observed } \\
\text { and calculated from }\end{array}$} \\
\hline & & & & & & & & Eq. (15) & Eq. (12) & Eq. (15) & Eq. (12) \\
\hline 2 & PE & 11 & 11100 & 10.25 & 0.09 & 0.180 & 0.96 & 10990 & 10540 & 110 & 560 \\
\hline 3 & PP & 11 & 11030 & 10.28 & 0.09 & 0.180 & 0.91 & 10990 & 10740 & 40 & 290 \\
\hline 5 & PS & 14 & 9810 & 8.46 & 0.09 & 0.184 & 1.05 & 9560 & 9490 & 250 & 320 \\
\hline 8 & $\mathrm{Ny}-6$ & 13 & 7480 & 9.15 & 0.12 & 0.259 & 1.10 & 7420 & 7570 & 60 & 90 \\
\hline 10 & PMMA & 10 & 6300 & 9.87 & 0.08 & 0.175 & 1.18 & 6350 & 6300 & -50 & 0 \\
\hline 30 & PVA & 12 & 5990 & 3. 73 & 0.06 & 0.224 & 1.29 & 5960 & 5900 & 30 & 90 \\
\hline 31 & PEO* & 11 & 6350 & 4.98 & 0.08 & 0.150 & 1.22 & 6230 & 5980 & 130 & 360 \\
\hline \multirow[t]{2}{*}{32} & PVAc & 13 & 5530 & 6.26 & 0.11 & 0.202 & 1.18 & 5510 & 5640 & 20 & 110 \\
\hline & Mean & & & & 0.09 & & & & & 86 & 228 \\
\hline \multicolumn{12}{|c|}{ Evaflex } \\
\hline 40 & $\begin{array}{l}\text { Evaflex } \\
40 \% \text {-VAc }\end{array}$ & 14 & 8760 & 9.30 & 0.11 & 0.219 & 0.97 & 8640 & 8780 & 120 & -20 \\
\hline 150 & $33 \%$-VAc & 13 & 9100 & 12.06 & 0.13 & 0.219 & $0: 96$ & 8940 & 8960 & 160 & 140 \\
\hline 460 & $20 \%$-VAc & 11 & 9950 & 10.00 & 0.10 & 0.202 & 0.94 & 9820 & 9680 & 130 & 270 \\
\hline 550 & $14 \%-\mathrm{VAc}$ & 13 & 10280 & 10.90 & 0.11 & 0.202 & 0.93 & 10090 & 9960 & 180 & 320 \\
\hline \multicolumn{12}{|c|}{ Et-PP copolymer } \\
\hline A & $\begin{array}{c}\text { Et-PP } \\
30 \%-P P\end{array}$ & 12 & 11060 & 10.25 & 0.09 & 0.175 . & 0.87 & 11030 & 10680 & 30 & 380 \\
\hline B & $40 \%-\mathrm{PP}$ & 11 & 11110 & 8.23 & 0.07 & 0.175 & 0.87 & 11030 & 10680 & 80 & 430 \\
\hline C & $50 \%$-PP & 11 & $11030^{\circ}$ & 9.16 & 0.08 & 0.175 & 0.87 & $11030^{\circ}$ & 10680 & 0 & 350 \\
\hline
\end{tabular}

Remarks, - s. d.: Estimated standard of deviation of universe. c. v.: Coefficient of variation in $\%$. $n$ : Sample size, * : Glass fiber wicked.

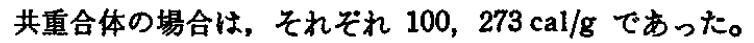
Et-VAc 共重合体の $O I$ 值は $O I$ の組成相加平均値より高く, Et-PP 共重合体の OI 值は組成相加平均值を越光ることはなか った。

\section{6 結論}

酸菜指数を構成する限界酸素, 窒素量が高分子物質の酸素指数 測定に打いて自己火炎拡散にどんな役割を演ずるがついて検討 した。検討の基整としてつぎの仮定をした。

1）窒素は一般に消炎奻果のみを考光勝ちではあるが，然焼生 成ガスと然焼熱をわけ合って生成ガスとともに熱流束を形成し火 炎伝播の仲介をする。このさい，窒菜および熱量の損失はない。

2）高分子物質 $1 \mathrm{~mol}$ が化学量諭的比率で酸素儿出会って酸 化然焼すると仮定する。かつ酸素は酸素指数組成に相等する窒素 で薄められている。窒素, 生成ガスの熱伝導係数, 熱容量は同 し。得られた結果はつぎのとおりである。

1. 高分子物質および軽油の燃焼熱, 酸素指数などの文献値を 使用して下記の式を誘導した。

$$
\begin{aligned}
& H_{\mathrm{cc}}\left(\mathrm{cal} / \mathrm{cm}^{8}\right)=1456+84220 L O\left(\mathrm{~mol} / \mathrm{cm}^{3}\right) \\
& H_{\mathrm{o}}(\mathrm{cal} / \mathrm{g})=744+92605 \mathrm{LO}(\mathrm{mol} / \mathrm{g}) \\
& O I=0.0126 M H E F(\mathrm{kcal} / \mathrm{mol})-0.036 \text { (高分子十軽油) } \\
& O I=0.0129 M H E F(\mathrm{kcal} / \mathrm{mol})-0.044 \text { (高分子のみ) }
\end{aligned}
$$

ここに, MHEFは限界熱流束平均熱エネルギー，OI は酸素指
数， $H_{\mathrm{cc}}$ は $1 \mathrm{~cm}^{\mathrm{s}}$ あたりの然焼熱 (cal), $H_{\mathrm{o}}$ は $1 \mathrm{~g}$ あたりの然 焼熱 (cal) であり，LO は限界酸帛量を示す。 $M H E F=H_{\mathrm{oc}}$ l $\left[\left(m_{\mathrm{p}}+m_{\mathrm{n}}\right) / M V\right], M V: 1 \mathrm{~mol}$ の容積 $\left(\mathrm{cm}^{3}\right), m_{\mathrm{o}}, m_{\mathrm{n}}, m_{\mathrm{p}}$ \& それぞれ軽油 $1 \mathrm{~mol}$ あるいは高分子 $1 \mathrm{~mol}$ を然焼するに要する 酸录指数組成雾团気の酸素, 窒素のモ儿数および生成ガスの総モ ル数を示す。

2. PVA, PVAc, PEO, Et-VAc 共重合体の $O I$ 値を $H_{\mathrm{ec}}-L O$ 式, $O I-M H E F$ 式に代入して然焼熱を求め両者の近似性を比較 した。

3. 単元，共重合体の燃焼熱，酸素指数を测定し，推定燃砝熱 が実測值との近似性を検討し，OI-MHEF 式が化学異性体の埸 合にるよく適合することを認めた。

4. エチンン-酷酸どニル共重合体，エチンンープロピレン共重 合体の酸素指数はそれそれれの単元重合体の $O I$ の相加平均値より 前者は高く，後者は相加平均值を越えることはなかった。

試料を供与されたクラレ, 日本ぜオン，三井石油化学，三井ボ ทケミカル, 三菱モンサント化成, 三洋化成, 住友化学, 東洋䊉 績の各社飞感謝する。引用した文献値はそれぞれ，The Combustion Institute (Pittsburgh), Carl Hanser Verlag (München). Centre D'Etude des Matières Plastique (Paris) より使用の培 可を得た。また密度値を連絡された Resopal Werk (GrossUmstadt) の Dipl.-Ing. P. Klimke, Directeur du CEMP Prof. M. Chatain ら火深い感謝を述べる。

(1974 年 5 月, 織椎学会年次大会(一部) 発表) 
Heats of Combustion of High Polymers and Their Oxygen Indices

Hideo OHE and Koichi MatsuURA

Department of Fibers and Color Chemistry ;

Fukui-shi 910 Japan

It was confirmed that the heat of combustion of high polymers could be calculated by the following four empirical equations including of the value of oxygen index $(O I)$.

$$
\begin{aligned}
& H_{\mathrm{co}}\left(\mathrm{cal} / \mathrm{cm}^{9}\right)=1456+84220 \mathrm{LO}\left(\mathrm{mol} / \mathrm{cm}^{9}\right) \\
& H_{\mathrm{o}}(\mathrm{cal} / \mathrm{g})=744+92605 \mathrm{LO}(\mathrm{mol} / \mathrm{g}) \\
& O I=0.0126 M H E F(\mathrm{kcal} / \mathrm{mol})-0.036 \\
& O I=0.0129 M H E F(\mathrm{kcal} / \mathrm{mol})-0.044
\end{aligned}
$$

where, $H_{\mathrm{cc}}$ and $H_{0}$ represent the heat of combustion per nuit volume and per unit weight, respectively.

$$
L O=m_{\mathrm{o}} / M V, M H E F=H_{\mathrm{co}} /\left[\left(m_{\mathrm{p}}+m_{\mathrm{n}}\right) / M V\right]
$$

where, $M V$ is a molar volume of light fuel or a volume of the molecule in a unit chain of polymers per repetition, respectively, $m_{0}$ and $m_{n}$ are stoichiometrical amounts of oxygen and nitrogen, again respectively, when polymers or light fuels continue their self-flame-combustion in the atomosphere under a certain $O I$ condition, and $m_{\mathrm{p}}$ is the number of moles of gaseous products produced in the flame.

The third equation can be applicable to high polymers and light fuels, whereas the other equations are limited to high polymers alone. 